\title{
難聴を主症状とした胸廓出口症候群症例
}

\author{
田島 文司*・川端五十鈴・池田 利昭
}

\section{A Case of Thoracic Outlet Syndrome with Hearing Loss}

\author{
Bunji Tajima, Isuzu Kawabata and Tosiaki Ikeda \\ (Saitama Medical Center Saitama Medical College)
}

A 37-year-old male visited our clinic complaining of acute onset of right hearing loss and vertigo in the morning after sleeping in the right lateral position with his arm abducted.

Audiological examination revealed sensorineural hearing loss (average pure tone level $70 \mathrm{~dB}$ ), probably of cochlear origin.

Angiography showed stenosis of thoracic outlet portion of the right subclavian artery. Hearing loss and other symptoms disappeared after several days of steroid therapy.

The pathogenesis of hearing loss in this syndrome is discussed briefly from the point of view of the disturbance of the circulation to the inner ear due to subclavian arterial stenosis.

Key words: thoracic outlet syndrome, subclavian arterial stenosis, sensorineural hearing loss and vertigo

\section{はじめに}

胸廓出口症候群 (Thoracic Outlet Syndrome，以下TOS之略す）は頸筋・前斜角筋

・第 1 肋骨など胸邡出口部を構成する臟器によ って腕神経叢や鎖骨下動・静脈が直接压迫さ れ，多彩な臨床症状を呈する疾患である ${ }^{122) 31}$.

しかし, 本症は多彩な神経症状や血液循環不全 の症状を呈するにもかかわらず，耳症状を伴う ことは少ないとされてきだ). 今回われわれは 急性に発症した蝸牛・前庭症状を主訴とした TOSの興味ある症例に遭遇した。その臨床経 過を報告するとともに，本症での難聴の発症原 因あるいは内耳の血行動態などについて文献を
引用しながら考察を加えたので諸賢の御批判を あおぐ次第である。

\section{症例報告}

患者:
男性
初診 : 昭和 61 年10月 3 日
主訴 : 右難聴, 浮動感
家族歴: 特記すべきととなし.
既往歴: 著患を知らず.
現病歴 : 20 代時にリュックサックを背負っ
て山登りの途中, リュックをおろして休んでい
ると右手のシビレ, 冷感を感じ, 左手と明らか
に違うととに気づいた（いわゆるリュックサッ


ク麻痷）がそのまま放置していた。昭和59年自 動車を運転し，後進させようと頭を右に向けた 時，首筋に痛みを感じ，同時に右手のシビレ感 が出現した. この年，某院の人間ドックにて右 のTOSと診断されたが放置して経過をみるよ うに言われた。昭和 61 年 9 月 26 日物が前後に動 く浮動感が出現し某大学病院にて精査したが問 題なしと言われた.

10月 2 日起床時, 右難聴 $\cdot$ 耳鳴 $\cdot$ 耳閉感自覚 的レクルートメント現象があり，また身体が前 後に動く浮動感, 後頭部痛が出現し翌日の 10 月 3 日当科受診し, 精査の目的で入院した。な お，10月 1 日の夜より翌朝まで右上肢外転外旋 右側臥位にて就寝していたと言う。

\section{1 . 入院時所見}

一般所見：体格栄養状態とあに良好な男子で ある．前腕の血圧は $130 \sim 70 \mathrm{mmHg}$ で左右差は ない. 脈拍数 80 /分で不整脈を認めない. 聴診 で呼吸音に異常ない. 血液, 生化学, 尿所見に も異常なく，心電図にて軽度の L V H, 呼吸性 洞性不整脈を認めた。

耳鼻咽喉科所見：鼓膜は正常で，鼻咽喉頭に 異常はない，頸部の触診で右鎖骨上三角に直径 $1 \mathrm{~cm}$ 弱の弾性でやや硬く, 可動性良好の腫瘤が
触診される屯雑音はない。

2 . 検査所見

聴力検査所見：純音聴力検査では図 1 に示す ごとく左耳は正常值であったが，右耳は皿型に 近いタイプの感音難聴がある. SISI 検査は陽 性で，自記オージオメーターで Jerger の II 型を示した. インピーダンスーオージオメータ 一のチンパノグラムは両耳とも $\mathrm{A}$ 型を示した.

平衡機能検査では Romberg 検査, 足踏検 査と屯に異常なく，自発眼振では水水にて右耳

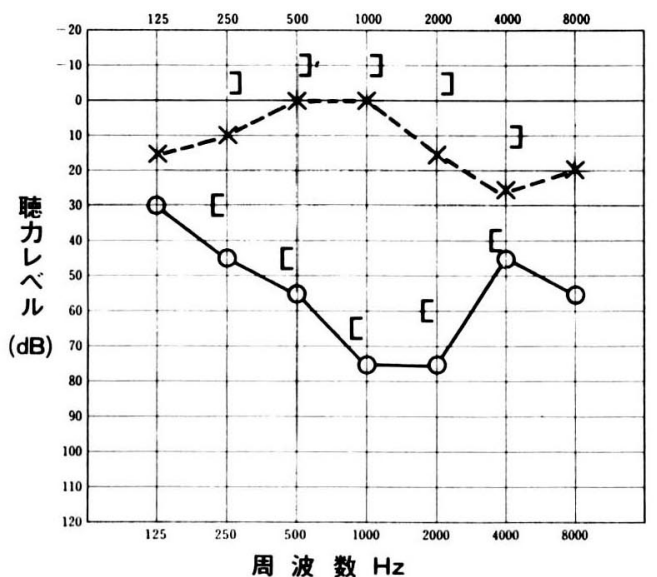

図 I 初診日（10月 3 日）の聴力図

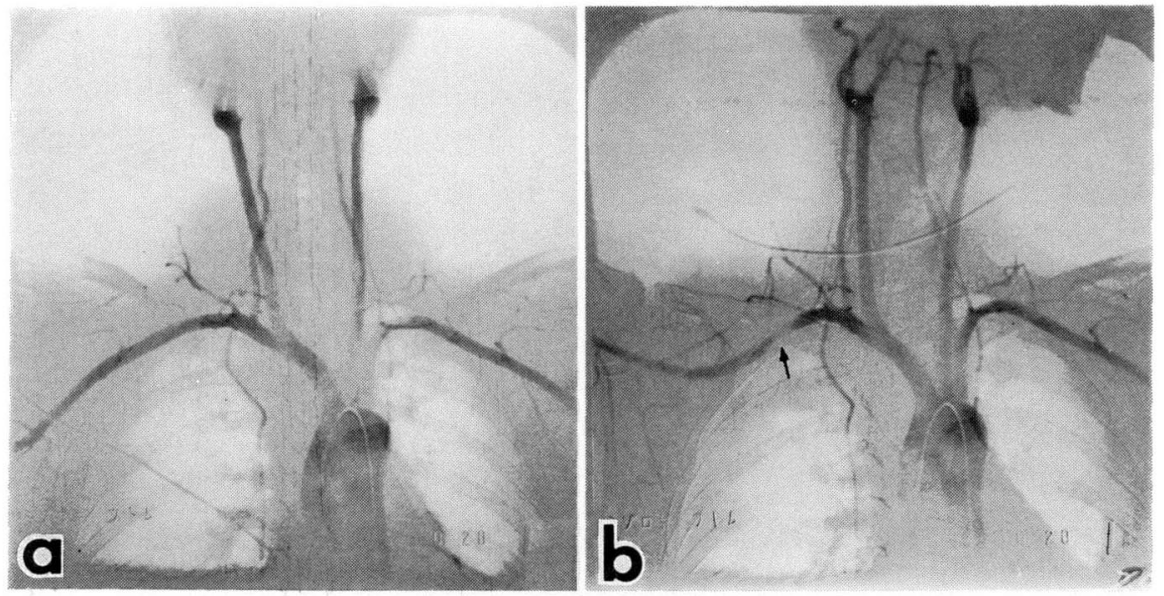

図 2 血管造影所見

$\mathrm{a}$ : 正常頭位 b : stress position 鎖骨下動脈の狭窄を示す (矢印)。 
は 3 分, 左耳は 3 分 30 秒で, 右耳に軽度の機能 低下を認好. 右の第 8 脳神経以外脳神経症状 はなく，また小脳症状も認めない。

レ線所見：中耳・内耳などの側頭骨のレ線所 見に著変なく，頸椎に異裳を認めない。

脈管テスト：TOSの診断のため下䛉の検查 を施行した. Wright Test, Moley Test は 右側のみ陽性で Adson test は左右とも陰性 であった。また坐位で右上肢挙上すると橈骨動 脈の拍動が消失した.

血管造影所見：TOSの確定診断のために行

表 I 自覚症状の経過

\begin{tabular}{|c|c|c|c|c|c|c|c|}
\hline 症状 & $\begin{array}{r}10 \text { 月 } \\
1 \text { 日 }\end{array}$ & 2 日 & 3 日 & 4 日 & 5 日 & 6 日 & 7 日 \\
\hline 難聴 & & H & H & + & \pm & - & - \\
\hline 耳 閉 & & + & \pm & - & - & - & - \\
\hline 耳 鳴 & & $H$ & $H$ & + & + & \pm & \pm \\
\hline 補态現象 & & + & + & - & - & - & - \\
\hline 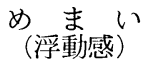 & & + & + & - & - & - & - \\
\hline 頭 重 感 & & $H$ & $H$ & + & + & \pm & - \\
\hline 頭痛 & $\begin{array}{l}\uparrow \\
\text { スポ } \\
\text { トシ } \\
\text { レシ } \\
\text { スン }\end{array}$ & & $\begin{array}{l}\text { 初覫 } \\
\text { 入院 }\end{array}$ & & & & \\
\hline
\end{tabular}

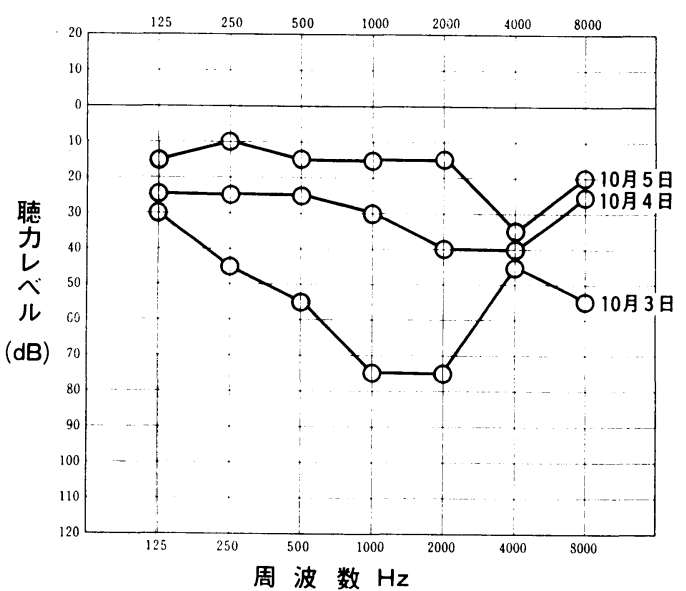

図 3 聴力回復過程を示す.
なった．図 2 a は頸中間位の血管造影所見で左 右の鎖骨下動脈に狭窄部位は認めない。図 $2 \mathrm{~b}$ は右上肢外転外旋位をとらせ頸左回旋位の状態 の血管造影所見である。乙れは発症前夜の睡眠 楺の姿勢にほぼ近い状態と思われる。乙の姿勢 すなわち stress position にて右鎖骨下動脈 の狭窄が肋鎖間隙で認められる (図 $2 \mathrm{~b}$ 矢印). この外径は狭窄がないときが $9 \mathrm{~mm}$ で狭窄をおこ したときが $4.5 \mathrm{~mm}$ と半分になっている。なお右 上肢外転外旋位で頸右回旋位のときは狭窄部位 の外径は $6 \mathrm{~mm}$ と $2 / 3$ になった。 また同時に椎骨 脳底動脈系も調べたが異常は認められなかっ た.

\section{3．治療および経過}

入院当日より㔖発性難聴に準じてステロイド の点游静注，嘋状神経節ブロック，循環改善 剂，ビタミン剂の内服を開始した。入院翌日に は自覚症状の藷叮な改善が認められた。すなわ ち白覚的に難聴は改澺し，聴力検查で屯図 3 の 如くである，また紙袋のすれる音や見舞いに来 た子供の高い声が不快でなくなったという。浮 動感も消失した。耳鳴之後頭部頭平感は入院日 と変わらなかった。入院 3 日目には聴力はさら

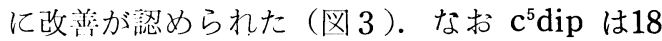
年閒騒咅下の仕可に従的していたためと考えら れる，耳鳴・项柋感も徐々に輅快を示した，発 症後の症状の経過を表 1 に示した。また右鎖骨 上三角にあった腫瘤は入院後 2 日には消失し た。発症後 1 年たった现在何の症状屯示してい ない.

\section{考察}

1. TOSについて

TOSの原因・病態・㹂床症状について今倳 の詳しい報告がある ${ }^{1)}$ ，概畍について述べる 之，本症は胸廓出口部において頸笳，前斜角 筇，第 1 肋骨などに腕神経叢や鎖骨下動・静脈 が南接压迫され多彩な神経症状やIIII管圧追症状 を生じるもので，比較的若い $20 \sim 30$ 代の文性 に多く発症する，左右差を瑟めない。目觉症状 は，神経症状を示す埸命が多く伹箈压追による 
症状は $5 \%$ 弱ともいわれる. 実際の症状とし て, 上肢疼痛, シビレ感, 冷感, 肩てり, 頭 痛, めまい等があげられる. 診断の決め手とし て脈管テストが重要であり, 鎖骨下動脈造影で 狭窄部位が見つかればほぼ診断がつく、治療と しては，姿勢・体位を考慮した保存的治療で経 過観察することが多いが，一方手術方法として は近年第 1 肋骨切除術が普及し良好な治療効果 を認めている ${ }^{3)}$.

\section{2 . 本症例の特徵}

本症例の特徴は急性に発症した同側耳の感音 難聴を伴ったTOSである. まず感音難聴につ いてTOSの報告をみると，めまいを訴えるこ とはあるが，難聴を合併する症例は非常に少な いようである，TOSの症状は同側の上肢の疼 痛, シビレ感が多く, T O S 30例を集計した Raskin ら ${ }^{4)}$ の報告ではその症状は嘔気18例, 嘔吐11例, 閃輝暗点11例, 羞明 9 例, 視力障害 6 例, メマイ感 5 例, 鼻閉 4 例, 耳鳴 2 例であ る. 一般にメマイ感, 耳鳴の症状はあるが明ら かな難聴症状の記載はないようである ${ }^{5 / 6) 71}$. そして Raskin ら ${ }^{4)}$ 椎骨脳底動脈系, 後大脳動 脈の視覚領域の循環不全による症状と推定して いる.

難聴が急性に発症し，また難聴の改善が著し いと言う臨床経過は本症例の第 2 の特徵であ る. 急性の難聴発症の原因として発症前夜の首 の位置, 上肢の体位を患者自身が指摘し得たの は20才代より長年にわたって頸部の位置で上肢 のシビレ, 浮動感・頭重などの症状が出現する ことを経験しているからであって，今回の急性 の難聴もそれに関連あるあのとして早期に受診 したようである. 本症例の蝸牛・前庭障害は同 側であり, 椎骨脳底動脈系の循環障害によるむ のと考えられ, 難聴の改善の著しいのもそのた めと推定される。われわれが施行した治療は循 環障害改善を促進したものであり，また，若年 者であって動脈硬化などの血管病変のないとと 屯症状の早期消退に関与していると思われる.

\section{3. 本症の難聴の成因に対する考察}

本症例の血管造影で, stress position にて 右の鎖骨下動脈の狭窄部位は椎骨動脈が分岐し た後の肋鎖間隙で生じて，その外径は $1 / 2$ となっ ている，ての埸合 poiseuille の法則によれば 末梢への血流量は $1 / 16$ を減じたと推定される. 残りの $15 / 16$ の血流量はどてに流れて行ったか が問題となる. 今回われわれは stress position での実際の椎骨動脈および総頸動脈の血 流量を測定していないが，しかし，椎骨動脈系 ・総頸動脈系に残りの $15 / 16$ が流入し，血流増 加・血压上昇を生じ蝸牛・前庭症状を呈したと 推定される，すなわち，原因として椎骨動脈系 の血流増加による循環障害が最屯考えられる.

椎骨動脈, 内頸動脈の血管反応性すなわち Autoregulation に差があるととは従来から指 摘されてきた ${ }^{8191011112)}$. 椎骨動脈系は内頸動 脈系よりも交感神経分布が踈なため血圧変動に 対して Autoregulation が劣っているといわ れている. 本症例のように stress position の状態で $7 \sim 8$ 時間の就寝という負荷によって 椎骨動脈系の血流増加により Autoregulation の破綻が生じたてとが想像される.むしてのよ うな破綻が生じた場合には, 血流が break throughするため組織での代謝障害を引き挔 こし, 内耳障害を生じた可能性む考えられる. 一方, 静脈の側からすれば venous return の 障害を生じ, 組織の浮腫の原因となるであろう が, 本症の難聴・補充現象の存在之直接に結び つくが，推定の域を出ない.

なお，入院 1 週間後臨床症状の消失した時点 で再度 stress position 下で ENG 之聴力検 查を施行したが，異常所見はみられなかった。

これは負荷時間が短いためと思われ，症状発 症には, 本症例の発症時のエピソードが示す如 く長時間の負荷洔間が必要であると思われる。

なお，頸の姿勢変化による椎骨動脈の血流減 少, 頸部交感神経の刺激により血管の spasm などにより内耳循環障害が抢てった可能性も十 分に考えられる．てれは結局“虚血”で病態 
を説明しょうとするあのであるが，本症例は TOSを基礎疾患として血管造影所見も考えむ しろ “増血”という観点より難聴の発症を考察 した.

\section{まとめ}

1 ）難聴を主症状としたTOSの一症例を報 告した.

2）原因として血流増加・血圧上昇により (1)椎骨脳底動脈系の Autoregulation の破綻, (2)代謝障害, (3) venous return の障害などの 観点から難聴の発症について考察を加えた。

\section{文献}

1 ) 今釜哲男：胸郭出口症候群の病態関する研究一 臨床的及び形態学的研究一. 日外宝 50 補 1 : 143 170, 1981.

2) Larry A Scher, et al : Vascular complicatons of thoracic outlet syndrome. J Vascular Sugery $3: 3 ; 565 \sim 568,1986$.

3 ) 立石昭夫: 胸郭出口症候群の手術. 神経外科 13 補 $8: 817 \sim 823,1985$.

4) Raskin A, et al : Headache as the leading symptom of the thoracic outlet syndrome. Headache $25: 4 ; 208 \sim 210,1985$.

$5)$ Riddel DH, et al : Thoracic and vascular aspect of thoracic outlet syndrome. Clin Orthop $207: 31 \sim 36,1986$.

6 ）似島俊明, 他: Sitting intravenous digital subtraction angiography 一胸郭出口症候群の応用
一. 臨放 $30: 633 \sim 636,1985$.

7 ) 不破誠行, 他: 胸郭出口症候群の 2 治験例. 胸部 外科 $38: 205 \sim 209,1985$.

8 ）丸木雄一：内頸動脈之椎骨動脈の血管反応性の比 較検討. 埼医大誌 $11: 331 \sim 338,1984$.

9) Knoche $\mathrm{H}$, et al : Sympathetic innervation of the carotid bifurcation in the rabbit and cat; blood vessels, carotid body and carotid sinus. A fluorescence and electron microscopic study. Cell Tissue Res 184:103 112, 1977.

10) Sercombe $R$, et al : Neurogenic influence on local cerebral blood flow ; effect of cathecholamines or sympathetic stimulation as correlated with the sympathetic innervation. Neurology $25: 954 \sim 963,1975$.

11) Muller SM, et al : Total and regional cerebral blood flow during hypotension, hypertension and hypocapnia ; effect of sympathetic denervation in dogs. Circ Res 41: 350 356, 1977.

12) Busija DW, et al : Effect of sympathetic nerves on cerebral vessels during acute moderate increases in arterial pressure in dogs and cats. Circ Res $46: 696 \sim 702,1980$.

$$
\left(\begin{array}{l}
\text { 原稿採択 : 昭和63年 } 2 \text { 月 } 23 \text { 日 } \\
\text { 別刷請求先 : 川端五十鈴 } \\
\text { T350 埼玉県川越市鴨田辻道町 } 1981 \\
\text { 埼玉医科大学総合医療センター耳鼻咽喉科 }
\end{array}\right)
$$

